\title{
Cystoblastus and the origin of the Hemicosmitoida (Echinodermata: Blastozoa)
}

\author{
Christopher R. C. Paul ${ }^{\mathrm{a}}$ and Ursula Toom ${ }^{\mathrm{b}}$ \\ a School of Earth Sciences, University of Bristol, Bristol, UK; glcrep@bristol.ac.uk \\ ${ }^{\mathrm{b}}$ Department of Geology, School of Science, Tallinn University of Technology, Ehitajate tee 5, 19086 Tallinn, Estonia; \\ Ursula.toom@taltech.ee
}

Received 14 December 2020, accepted 5 July 2021, available online 12 August 2021

\begin{abstract}
All previous descriptions and interpretations of thecal plating in Cystoblastus Volborth depict a closed infralateral circlet, whereas actual specimens have that plate circlet open in three places. Cystoblastus is redescribed using Estonian specimens. It has a blastoid-like theca composed of a pelvis of four basals and five infralaterals, plus a vault composed of nine alternating laterals and radials. The radials are deeply cleft to accommodate the ambulacra, as in many blastoids, but lack underlying lancets, or any trace of blastoid deltoid plates. Cystoblastus vault plating resembles the 'lateral' circlet of hemicosmitoid Rhombifera. So, recognition of plate homologies between glyptocystitoid and hemicosmitoid (= dichoporite) rhombiferans was attempted. One unique interpretation accounts for all the hemicosmitoid plates without contravening any positional constraints imposed by glyptocystitoid plating. Thus, the new interpretation is not invalidated by conventional tests of homology. We used the new plate homologies to investigate the phylogeny of glyptocystitoids and hemicosmitoids, utilizing twelve genera and 27 parsimony-informative characters. Cladistic analysis using PAUP produced eight equally parsimonious trees. A strict consensus tree revealed the hemicosmitoids as highly derived dichoporites, with Hemicosmites as sister to the Caryocrinitidae and Thomacystidae. Cystoblastus is a sister group to hemicosmitoids in a trichotomy including Glyptocystella and Pirocystella. This lineage was derived from the Cheirocrinidae. Thus, Cystoblastus is not related to blastoids, as suggested by Otto Jaekel, but is a critical link between glyptocystoid and hemicosmitoid dichoporites, and the Dichoporita is a valid taxon.
\end{abstract}

Key words: Blastozoa, Glyptocystitoida, Cystoblastus, Hemicosmitoida, plate homology.

\section{INTRODUCTION}

During the preparation of another paper on Blastozoa with tetraserial ambulacral axes (Paul 2021), one of us noticed similarities between the thecal plate arrangement of the glyptocystitoid genus Cystoblastus Volborth, 1867 as published in the Treatise (Kesling 1968) and those of hemicosmitoids. Both Cystoblastus and hemicosmitoids are part of the tetraserial blastozoan lineage, so it seemed possible that Cystoblastus might provide a link between the glyptocystitoids and hemicosmitoids. A quick perusal of the excellent website 'Geocollections of Estonia' provided a few photographs of Cystoblastus kokeni Jaekel, 1899. It became immediately apparent that the published plate arrangements for both species of Cystoblastus (Kesling 1968, figs 77.1e and 77.1f) did not match the actual specimens of $C$. kokeni. Subsequent investigation confirmed that all published illustrations of Cystoblastus depicted the plate arrangement inaccurately (compared with actual specimens of C. kokeni Jaekel, 1899) and almost certainly derive from Volborth's original plate diagram for the type species $C$. leuchtenbergi (Volborth 1867, pl. 1, fig. 1). So, we made contact and discussed the possibility of redescribing Cystoblastus to a modern standard, which is the first aim of this paper.

Once an accurate plate diagram for Cystoblastus had been produced, the possibility of interpreting the lowest three plate circlets of all hemicosmitoid rhombiferans in terms of standard glyptocystitoid plate terminology was investigated. Eventually, it became apparent that a single interpretation of hemicosmitoid thecal plates, which satisfied both the numbers of plates present in hemicosmitoids and traditional positional constraints in glyptocystitoids was possible, but only one. Thus, the second aim of this paper is to present the new interpretation of hemicosmitoid thecal plating.

Finally, having introduced a new interpretation of homologous extraxial thecal plates in glyptocystitoid and

(C) 2021 Authors. This is an Open Access article distributed under the terms and conditions of the Creative Commons Attribution 4.0 International Licence (http://creativecommons.org/licenses/by/4.0). 
hemicosmitoid rhombiferans, we have applied it to investigate the evolution of these dichoporite rhombiferans using character analysis. So, the third aim of this paper is to present the results of the new cladistic investigation. Jaekel (1899, p. 227; 1918, p. 104) argued that Cystoblastus was ancestral to the blastoids, largely due to similarities in the gross morphology of its theca. Here we reject that interpretation, but suggest that Cystoblastus was equally important in the lineage that gave rise to the hemicosmitoid rhombiferans. This has the further consequence that the Dichoporita, which includes only glyptocystitoid and hemicosmitoid Rhombifera, can be reinstated as a valid taxon within the Blastozoa. First, it is essential to describe the basic morphology of Cystoblastus. We base this on specimens of $C$. kokeni Jaekel, 1899, as the unique type specimen of $C$. leuchtenbergi had already been lost by the time Jaekel described C. kokeni.

\section{METHODS}

Specimens were borrowed from the University of Tartu and photographed specifically for this research. To produce an accurate plate diagram, the complete specimen (TUG 1086-3) was photographed at a standard magnification with each individual plate centred in a separate image. Outlines of plates were then drawn on each image and the outlines assembled into the pattern illustrated herein. Finally, the colours and plate identities were added. Interpretations of any ambiguous plate homologies were resolved by adhering to standardized positional relationships of all other glyptocystitoid cystoids. So, for example, the basal plate closely associated with pectinirhombs is always B2; the large basal with an infralateral directly above it is always B4 and the infralateral above is always IL4, and so on.

The same principles were adhered to in deriving the new interpretation of hemicosmitoid plates, even though certain landmarks were not available. For example, all basal plates of hemicosmitoids contribute to cryptorhombs, so it is more difficult to recognize individual basals. In the process it was discovered that the original plate numbering, adopted by Paul $(1969,1984)$ for Thomacystis Paul, 1969, by Frest (1975) for Caryocrinites Say, 1825 and by Bockelie (1979) for Hemicosmites von Buch, 1840 , all differed slightly from the pattern adopted here. This was primarily because in the original papers no attempt was made to relate hemicosmitoid plate arrangements to those of glyptocystitoids. The numbering of plates in hemicosmitoid plate circlets started as near the same radius in the theca as was possible, and plates were counted clockwise in oral view to the highest number. The plate arrangement was not thought to be homologous with that of any taxon outside the superfamily
Hemicosmitoida Jaekel, 1918. Plate numbering was merely to enable taxonomic descriptions to refer to individual plates. It was only necessary for the plate numbering to be consistent within the Hemicosmitoida. The new interpretation does imply homology between the hemicosmitoids and glyptocystitoids and so requires that in both superfamilies plates with the same designation must bear the same topographic relations to all adjacent plates for their homology to be acceptable. Since four basal plates occur in all taxa of both superfamilies, except Thomacystis where there are only three, homologies of individual plates were identified starting with the extra plate in the infralateral circlet of hemicosmitoids and working adorally.

A phylogenetic analysis of twelve relevant genera was undertaken using PAUP (version 4.b168, Swofford 2003). All characters were unordered, equally weighted and parsimony informative. The analysis was parsimonybased, used a branch and bound search and was rooted on Macrocystella Callaway, 1877.

\section{SYSTEMATIC PALAEONTOLOGY}

Measurements, terminology and repository. Measurements (in millimetres) were made from enlarged photographs of specimens with a scale included. The theca of Cystoblastus consists of 18 plates arranged in definite circlets called, from the stem attachment upwards, Basals (symbol B, plural BB), Infralaterals (IL, ILL), Laterals (L, LL) and Radials (R, RR). The plate circlets in which all the plates are in contact so they would form a complete ring if isolated from the rest of the theca, are referred to as closed (Regnéll 1945, p. 91). The circlets in which plates of the circlet above and below meet at a common suture, thus interrupting the circlet, are referred to as open. Specialized respiratory structures, called pectinirhombs, are developed on two plates with the canals (dichopores) orientated perpendicular to the plate suture between the plates (Paul 1968b). The positions of pectinirhombs within the theca are indicated by the plate symbols for the two plates that bear the rhomb. Measurements of pectinirhombs were made according to the system proposed by Paul (1968b, fig. 5, p. 700) where rhomb length is measured parallel, and width perpendicular, to the length of the canals or dichopores. Slit spacing was measured across ten slits and ten inter-slit spaces and is expressed as an average, 1 slit per 0.xxx mm. Half rhombs with longer and narrower slits are considered to be entrances and the plates that contain them are referred to with the entrance first. Thus, rhomb B2:IL1 implies that sea water entered the slits in plate B2 and exited from plate IL1. In general, both plate and rhomb terminology follow Paul (1984, p. 77, et seq.). The terms 'primary' and 'secondary flooring plates' (Paul 1967, fig. 10, p. 319) are best avoided as it is now known 
that during the growth of the ambulacra the secondary plates were the first formed and the primary formed second (Paul 2021, fig. 8, p. 47). Adoral and aboral floor plates are better terms. The specimens described here are deposited in the Geological Collections of the Natural History Museum, University of Tartu (TUG).

Class BLASTOZOA Sprinkle, 1973

Superfamily GLYPTOCYSTITOIDA Bather, 1899

Family CYSTOBLASTIDAE Jaekel, 1899

Diagnosis. Glyptocystitoids with a globular theca in which the basal and infralateral plates form an aboral cup or pelvis and the elongate laterals and radials alternate to form a domed vault. Plate formula of 4 BB, 5 ILL, 4 LL (L5 is missing) and $5 \mathrm{RR}$. Infralateral circlet open at three places, so B1:L1, B2:L2 and B3:L3 sutures exist. Vault composed of nine plates only, five radials and four laterals. Periproct small, surrounded by plates IL4, L4 and $\mathrm{R} 5$, in the AB interradius. Ambulacra elongate, developed in deep sinuses in the radial plates, such that the radials are divided into an aboral radial body and adoral radial limbs, very like the radials of most blastoids. Ambulacral axis formed of a double biseries of floor plates that form part of the body wall. Each ambulacral facet shared by a smaller, outer, adoral and a larger, aboral floor plate, which reaches the midline of the ambulacrum.

Genera included. Only Cystoblastus Volborth, 1867; the family is monotypic. Kesling (1968, p. S171) included Hesperocystis Sinclair, 1945, but that genus has since been shown to belong in the family Glyptocystitidae Bather, 1899 (Sprinkle 1982, p. 252).

Occurrence. Middle and Upper Ordovician, Baltica. Darriwilian and Sandbian of the St Petersburg region, Russia (Jaekel 1899; Yakovlev 1926a, 1926b, 1931); Lower Sandbian of Estonia (Bekker 1921; Öpik 1925; Yakovlev 1926a, 1926b, 1931), and possibly Upper Sandbian of Norway (Bockelie 1984, p. 8).

Remarks. Cystoblastus is unique among glyptocystitoid rhombiferans in having a theca with lateral plates that alternate regularly with the radial plates. In addition, only the cheirocrinid genus Sprinkleocystis Broadhead \& Sumrall, 2003 and Cystoblastus have four lateral plates. All other glyptocystitoid genera have five laterals. Several genera have open lateral circlets, but this usually occurs only between L2 and L3. Contrary to all previously published descriptions and illustrations, Cystoblastus has an infralateral circlet open in three places; only plates IL3, IL4 and IL5 have common sutures. The periproct is relatively small and surrounded by three plates, IL4, L4 and R5. Again, it is most unusual for any glyptocystitoid to have a radial plate contribute to the periproct border. In the glyptocystitid Hesperocystis Sinclair, 1945 the callocystitids Novacystis Paul \& Bolton, 1991 and the unique holotype of the type species of Trimerocystis, $T$. pecularis Schuchert, 1904, R4 contributes to the periproct border. Kesling (1961, p. 258) concluded that the only known specimen of Trimerocystis was an aberrant Pseudocrinites Pearce, 1843, with an extra ambulacrum. Novacystis is only known from two specimens, but both confirm that plate R4 does contribute to the periproct border (Paul \& Bolton 1991, p. 36; Sumrall \& Brett 2002, p. 737). The periproct of Cystoblastus lies in the AB interradius of Carpenter $(1884,1891)$, whereas most other glyptocystitoids have the periproct in the $\mathrm{BC}$ interradius. The periproctal cover of Cystoblastus is unknown, as it is in Hesperocystis also.

The earliest glyptocystitoid families are characterized by a closed radial circlet of six (rarely ten) plates. The families Callocystitidae Bernard, 1895, Echinoencrinitidae Bather, 1899, Rhombiferidae Kesling, 1962 and Cystoblastidae all have only five radials. Plate R5 fails to develop in the first two families; plate R6 is absent in the Rhombiferidae. In Cystoblastus the missing plate could be either R4 or R5 (see Remarks below). Here the five radials in Cystoblastus are interpreted as R1-R3, R5 and R6. Plates R5 and R6 have a common suture because plate L5 is missing. Thus, the vault of Cystoblastus is composed of a circlet of nine plates, which again is unique among glyptocystitoid rhombiferans. From the taxonomic point of view, both the family and genus seem well established.

\section{Genus Cystoblastus Volborth, 1867}

Type species. Cystoblastus leuchtenbergi Volborth, 1867, by monotypy, possibly from the Vaginatenkalk of Katlino, near Pavlovsk, St Petersburg region, Russia. According to Kröger (2012), the Vaginatenkalk corresponds to the Kunda Regional Stage (Darriwilian). Yanishevskii (1932) correlated the Orthoceras and Echinosphaerites limestones with the upper Kunda and Aseri regional stages, which were exposed in the Katlino area.

Other species. Cystoblastus kokeni Jaekel, 1899, from the Kukruse Regional Stage, Viivikonna Formation (Sandbian), Kukruse, Kohtla and Tallinn, Estonia and the old oil shale mine in Veimarn, St Petersburg Region, Russia.

Stratigraphic distribution. Middle and Upper Ordovician (Darriwilian and Sandbian).

\section{Cystoblastus kokeni Jaekel, 1899}

Figures 1-5

1899 Cystoblastus kokeni Jaekel, p. 230, pl. 16, fig. 2, text-fig. 12, p. 223.

1921 Cystoblastus kokeni Jaekel, Bekker, p. 32.

1925 Cystoblastus kokeni Jaekel, Öpik, p. 18, pl. 2, fig. 18. 
1926a Cystoblastus kokeni Jaekel, Yakovlev, pp. 4344, text-figs 1, 2, pl. 1, figs 1, 1a.

1926b Cystoblastus kokeni Jaekel, Yakovlev, pp. 2526, text-figs $1,2$.

1931 Cystoblastus kokeni Jaekel, Yakovlev, p. 43, fig. 1.

1933 Cystoblastus kokeni Jaekel, Wanner, p. 490, fig. 16.

1943 Cystoblastus kokeni Jaekel, Bassler \& Moodey, pp. 35, 149.

1952 Cystoblastus kokeni Jaekel, Piveteau, p. 615, fig. 10. [check]

1964 Cystoblastus kokeni Jaekel, Hecker, p. 40, textfigs 26, 27, pl. 4, figs 1, 2.

1967 Cystoblastus kokeni Jaekel, Jefferies et al., p. 567.

1968 Cystoblastus kokeni Jaekel, Kesling, fig. 77.1f, p. S175, fig. 79 , p. S177.

2014 Cystoblastus, Rozhnov, fig. 1b, p. 172.

Holotype. Original of Jaekel, 1899, pl. 16, fig. 2 (University of Königsberg?), from the Kuckers (now Kukruse) Shale, Kukruse, Estonia (= Kukruse Regional Stage, Viivikonna Formation, Lower Sandbian, Kukruse, Estonia).

Figured material. TUG 1086-3, 1727-548.

Diagnosis. A large species of Cystoblastus (ca $30 \mathrm{~mm}$ diameter) with a globular theca in which the basal cup or pelvis forms a quarter of the thecal height and the vault the other three quarters, with long ambulacra that taper from about 5-6 mm orally and lie in deep radial sinuses with distinct raised rims, slit-spacing of rhombs about 1 slit per $0.28 \mathrm{~mm}$ in vault rhombs and $0.25 \mathrm{~mm}$ in basal rhombs. Stem with outer proximal flanges curved down over columnals below and with sharp edges.

Description. Only proximal stem known in TUG 1727548 , which preserves seven outer proximal columnals and tapers from $10 \mathrm{~mm}$ diameter at the theca to $8.6 \mathrm{~mm}$ at the base of the preserved portion (Fig. 2B). Outer proximal columnals are blade-like, but curved down aborally and cover the outer proximal below. The specimen illustrated by Hecker (1964, pl. 4, fig. 2) shows a proximal stem that tapers gradually and is composed of more than 30 outer proximal columnals.

The theca is relatively large, up to $30 \mathrm{~mm}$ in diameter and height, with a distinct aboral cup or pelvis formed by the basals and infralaterals that occupies the lower quarter of the cup and a high, domed vault composed of the laterals and radials (Fig. 1C). Basally there is a hollow to receive the stem (Fig. 1A), which is rounded hexagonal. The four basals form a closed circlet, with $\mathrm{B} 2$ bearing two half rhombs (Figs 1A, C, 2F) and B4 lying directly below IL4 (Fig. 1A, below) which in turn is directly below the periproct (Fig. 3). The infralateral circlet is open at three places (Figs 1C-E, 3). There are three basal:lateral sutures, $\mathrm{B} 1: \mathrm{L} 1, \mathrm{~B} 2: \mathrm{L} 2$ and $\mathrm{B} 3: \mathrm{L} 3$. Of these, the B3:L3 suture (Fig. 1E) is the largest at nearly $2.6 \mathrm{~mm}$, whereas the B1:L1 suture (Fig. 1D) is about $2 \mathrm{~mm}$ wide and the B2:L2 suture only 1.2 and $2.1 \mathrm{~mm}$ in TUG $1727-458$ (Fig. 2D) and 1086-3 (Fig. 1C), respectively. The B2:L2 suture is sinuous and laterally symmetrical (Figs 1C, 2D, 3). Both the B1:L1 (Fig. 1D) and B3:L3 (Fig. 1E) sutures slope down towards the anterior of the theca, where plates B2 and L2 lie. Directly opposite is the L4:R5 suture, which terminates at the periproct below (Fig. 3). Thus, there is an anteriorposterior plane of symmetry within the pelvis of the theca.

The vault is composed of nine plates, five radials and four laterals, which alternate and bear demi-rhombs across all their common sutures (Fig. 1C-I). The lateral plates (Fig. 1C-E, G) are widest just above their bases, about 6$8 \mathrm{~mm}$ wide and taper upwards to just under $3 \mathrm{~mm}$ adorally, except that L4 tapers to a point (Fig. 1G). This makes L4 distinctive as the slits for both half demirhombs virtually touch along the centre of the plate (Fig. 1G). Plate L5 is entirely missing, so a single demirhomb crosses the R5:R6 suture (Fig. 1F) between ambulacra $\mathrm{B}$ and C. All other interrays have a lateral plate centrally and so two demirhombs between the radii.

The five radial plates are deeply cleft by a central sinus (Figs 1B, 3). Both radii visible in TUG 1727-458 show that the radial plates do not continue below the ambulacral plates within the radial sinuses (Fig. 2C, E, above). The ambulacra, which reach 16-17 mm long, cover the central sinus, which has a distinct peripheral rim (Fig. 2C, E). Ambulacra taper from about $6 \mathrm{~mm}$ adorally, to a point aborally and are estimated to have had about 40 facets each. TUG 1727-458 reveals some details of the construction. The main food groove is about $0.7 \mathrm{~mm}$ wide and gives rise to oblique lateral food grooves about $0.25 \mathrm{~mm}$ wide that terminate in almost circular facets about $0.75 \mathrm{~mm}$ diameter (Fig. 2C, E). Each facet is supported by a smaller, outer floor plate adorally and a larger aboral floor plate that reaches across the ambulacrum from the outer edge to the central zigzag suture (Figs 2E, 4). The ambulacra are surrounded by a very distinct raised rim (Fig. 2A, C, E) with a slightly asymmetrical swelling at the aboral tip. Plate L2 is anterior in the theca, and the vault is composed of four plates on either side of $\mathrm{L} 2$. The posterior two plates meet at the L4:R5 suture above the periproct. Thus, again there is an anterior-posterior plane of symmetry within the vault of the theca.

The oral surface is considerably obscured by sediment in TUG 1086-3 (Fig. 1B), but it is possible to distinguish three, interradial plates adorally as originally reported by Jaekel (1899, fig. 42, p. 223). These orals have lobes extending into the three lateral plates that do not taper to a point, L1-L3 (Fig. 1B, below, left and upper left). The specimen illustrated by Rozhnov (2014, fig. 1b) is better 

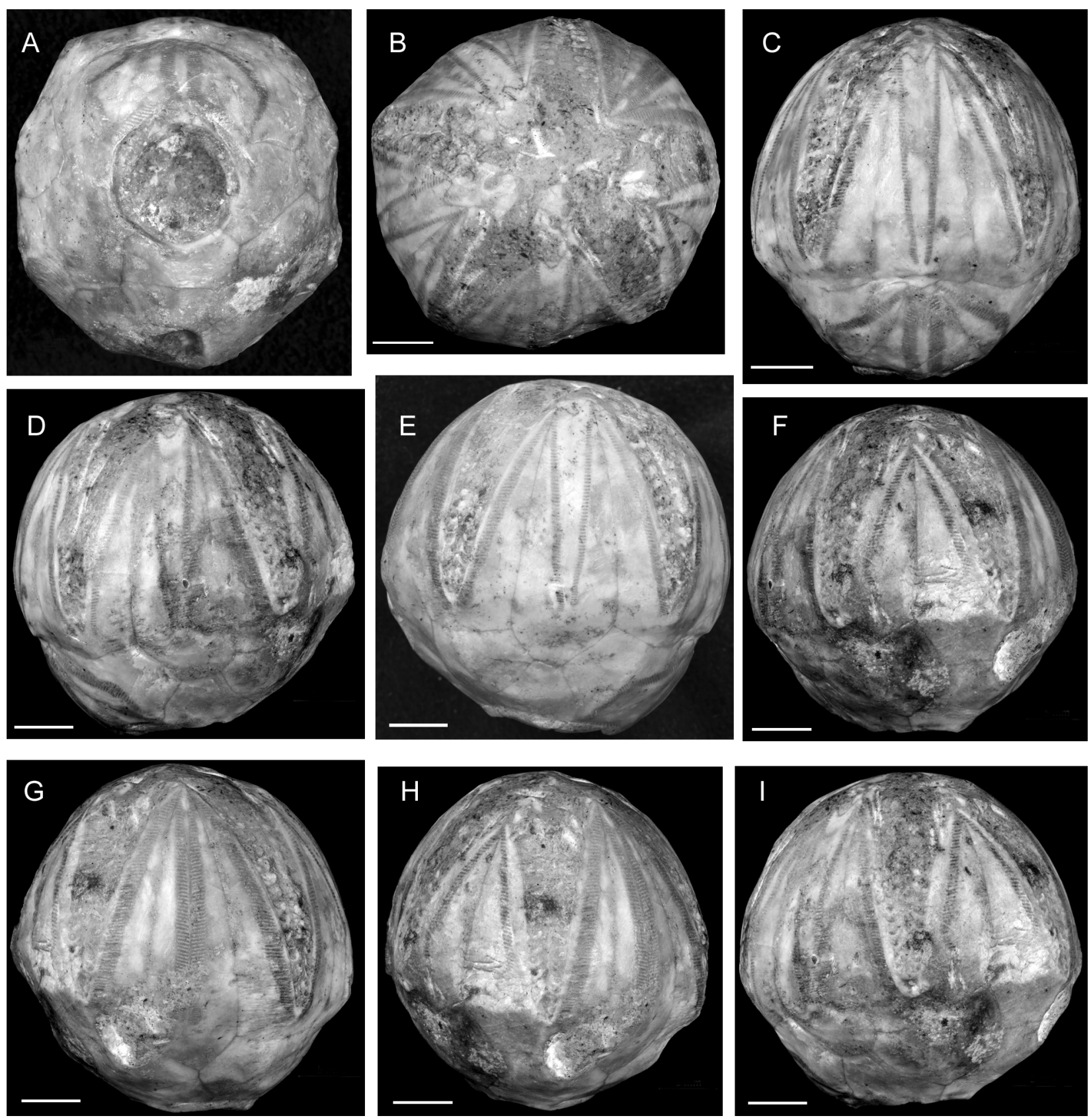

Fig. 1. Photographs of Cystoblastus kokeni Jaekel, TUG 1086-3, Kukruse Regional Stage (Viivikonna Formation), Tallinn, Estonia. A, basal view showing recess for stem, two basal pectinirhombs (above) and periproct (below). B, oral view showing five ambulacra. C, anterior lateral view showing basal pectinirhombs and short B2:L2 suture, thus IL1 with half rhomb on right is not in contact with IL2 with half rhomb on the left. D, lateral view centred on B1:L1 suture separating IL5 (right) from IL1 (left). E, lateral view showing B3:L3 suture separating IL2 (right) from IL3 (left). F, lateral view showing R4:R6 suture with no lateral plate between the radials. G, lateral view showing L4 which comes to a point adorally (top). H, posterior lateral view showing small, circular periproct (below). I, lateral view centred on ambulacrum $\mathrm{C}$ showing traces of facets below. Specimen uncoated to enhance plate sutures. All scale bars $=5 \mathrm{~mm}$.

preserved (Fig. 5A) and reveals that the five ambulacra are arranged in a 2-1-2 pattern around an oval mouth. Ambulacra B and D have the first two ambulacral facets developed to the left as viewed aborally in the direction of growth (F, Fig. 5C), whereas ambulacra A, C and E only have the first facet to the left. Thereafter, in all ambulacra the facets alternate left and right regularly. The feeding structures that arose from the ambulacral facets 

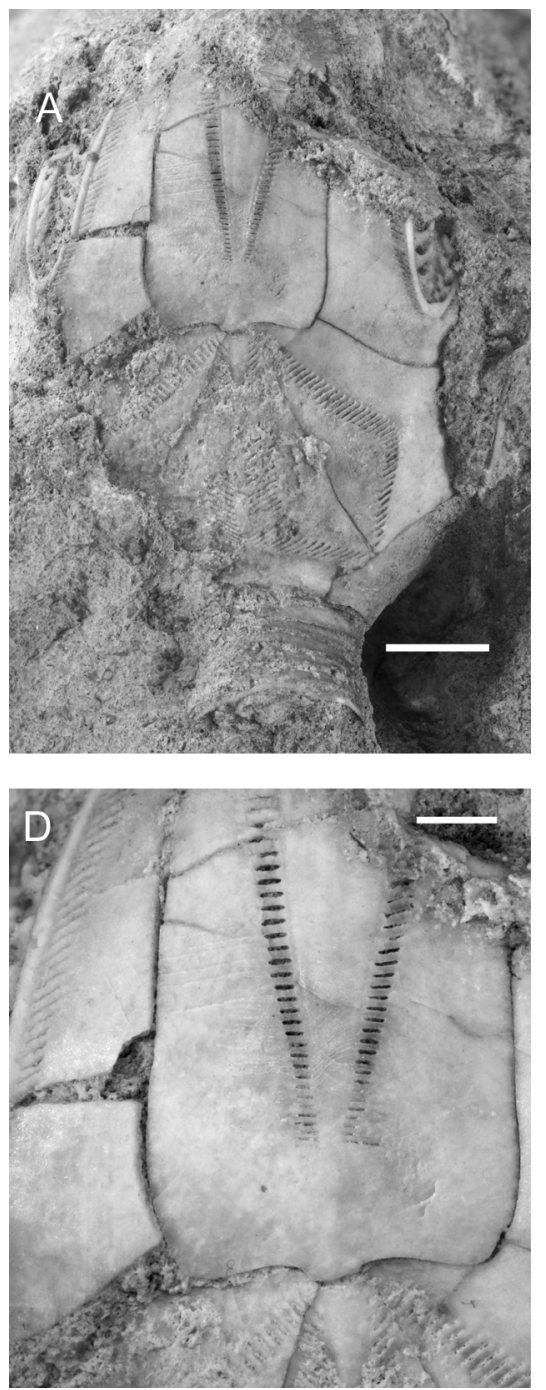
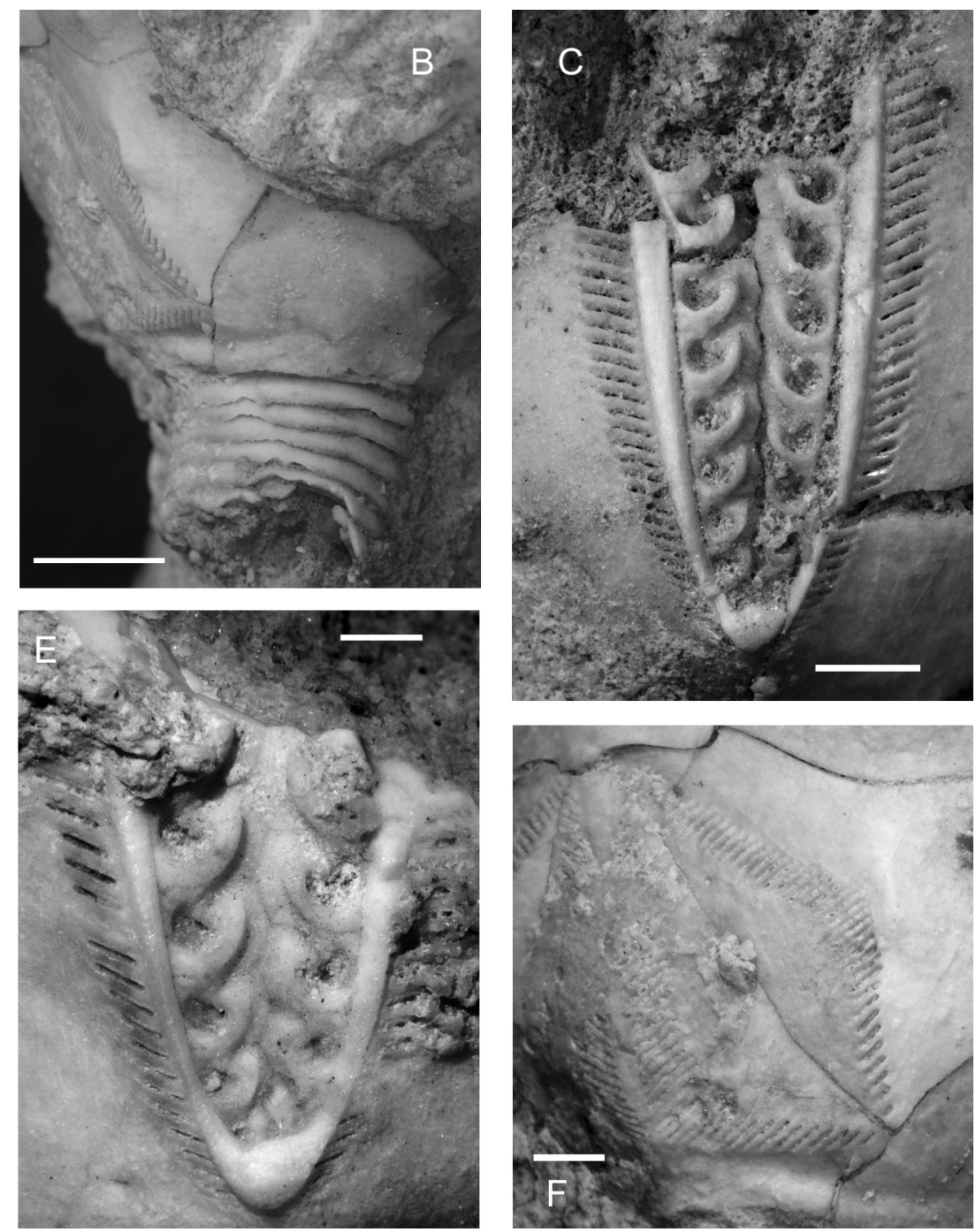

Fig. 2. Photographs of Cystoblastus kokeni Jaekel, TUG 1727-548, Kukruse Regional Stage (Viivikonna Formation), Kohtla, Estonia. A, general view of partial theca showing anterior view. B, close up of the proximal stem showing overlapping flanges of outer columnals. C, detail of ambulacrum E showing the main food groove with zigzag suture between floor plates and lateral food grooves ending in circular facets. Note the thick ambulacral rim, swelling at the tip and relatively long and thin slits for the pectinirhombs. D, detail of base of plate R2 and its suture with IL2, B2 and IL1 (from left to right). Note the base of plate R2 is sinuous and symmetrical and the lowest pectinirhomb slit on the right extends towards the right suture. $\mathbf{E}$, detail of the tip of ambulacrum $\mathrm{D}$ showing the plate sutures, ambulacral rim with terminal swelling and pectinirhomb slits. F, detail of basal pectinirhomb B2:IL1. Note the slits in B2 (lower left) are narrower and longer than those in IL1 (upper right). Scale bars $=5 \mathrm{~mm}(\mathbf{A}, \mathbf{B}), 3 \mathrm{~mm}(\mathbf{C}) \mathrm{and} 2 \mathrm{~mm}$ (D-F).

are unknown, but it would be astounding if they were not biserial brachioles. Rozhnov informs us that the gonopore and hydropore lie across the O6:O1 suture, with the latter adoral, as in most other glyptocystitoids.

Remarks. All previous illustrations of the plate arrangement in Cystoblastus show a closed infralateral circlet. In fact, the infralateral circlet of Cystoblastus is open in three places. An infralateral circlet open in three places also occurs in the cheirocrinid genus Cheirocrinus Eichwald,
1856 (Fig. 6), where the same three B:L sutures exist and the B2:L2 suture is the shortest. Thus, the infralateral circlet in Cystoblastus is not unique. Nevertheless, Cheirocrinus is unlikely to be the direct ancestor or closest sister group to Cystoblastus because of other significant morphological differences. All cheirocrinid genera have six radials and all but Sprinkleocystis have five laterals, so any transition from Cheirocrinus to Cystoblastus involved not only the interpolation of the individual lateral and radial plates, but a loss of one plate from both plate 


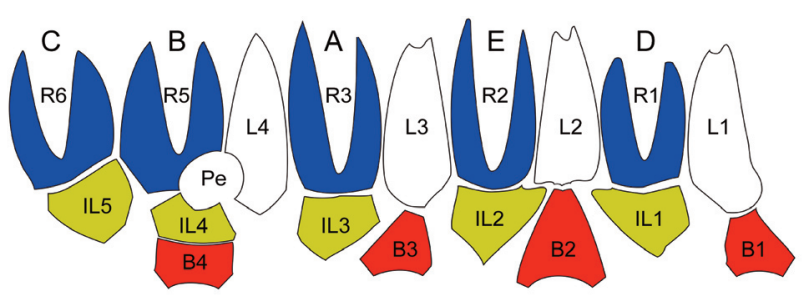

Fig. 3. Arrangement of thecal plates in Cystoblastus kokeni Jaekel, TUG 1086-3, Kukruse Regional Stage (Viivikonna Formation), Tallinn, Estonia. A-E, ambulacra according to Carpenter (1884, 1891); B1-B4, basal plates; IL1-IL5, infralaterals; L1-L4, laterals; Pe, periproct surrounding the anus; R1-R3, R5, R6, radial plates. See text for further explanation.

circlets. Furthermore, all cheirocrinid genera except Sprinkleocystis have a large lateral periproct surrounded by five plates, IL4, IL5, L1, L4 and L5. Sprinkleocystis has four periproct border plates; it lacks plate L5 altogether. Cystoblastus, in contrast, has a small lateral periproct surrounded by plates IL4, L4 and R5. So, again there are significant differences in the details of the periproctal regions in both genera.

The interpretation of the homologies of the individual thecal plates can be tested by positional arguments. The standard glyptocystitoid plate arrangement was established in the Tremadoc genus Macrocystella Callaway, 1877 (Fig. 7). Jaekel's (1899) system of denoting plate circlets, as modified by Regnéll (1945), produces the plate numbering shown in Figs 6 and 7. Plates of successive circlets are arranged alternately, so that if the radials are radial by definition, the infralaterals are also radial, whereas the laterals and basals are interradial. As there are only four basals, one, B4, is larger (usually wider) than the other three. So, the numbering starts with the basal immediately left of B4 and proceeds clockwise as seen in oral view. Thereafter, the arrows in Fig. 7 indicate where the numbering starts in each successive circlet. In glyptocystitoids it soon becomes apparent that this convention is related to other more fundamental internal anatomical features. So, for example, B2 is always associated with basal pectinirhombs. No other basal bears a complete half rhomb. Even in Macrocystella, which lacks true pectinirhombs but has folded plates, there are more folds in B2 than in other basal plates. Plate IL4 sits directly above B4 and almost always forms part of the periproct border. The extra radial plate, $\mathrm{R} 5$, sits directly over L5. When the number of radials is reduced to five, it is most often R5 that fails to develop. In most callocystitids and some echinoencrinitids, L5 interrupts the radial circlet. It occupies the position of both L5 and R5 in cheirocrinids. All of these features tend to confirm that the plate numbering really does refer to homologous plates and that variations in the plate arrangements, such as the interpolation of the radials and laterals in Cystoblastus, have evolutionary significance.

The detailed interpretation of individual plates in Cystoblastus (Fig. 3) is relatively straightforward. Of the
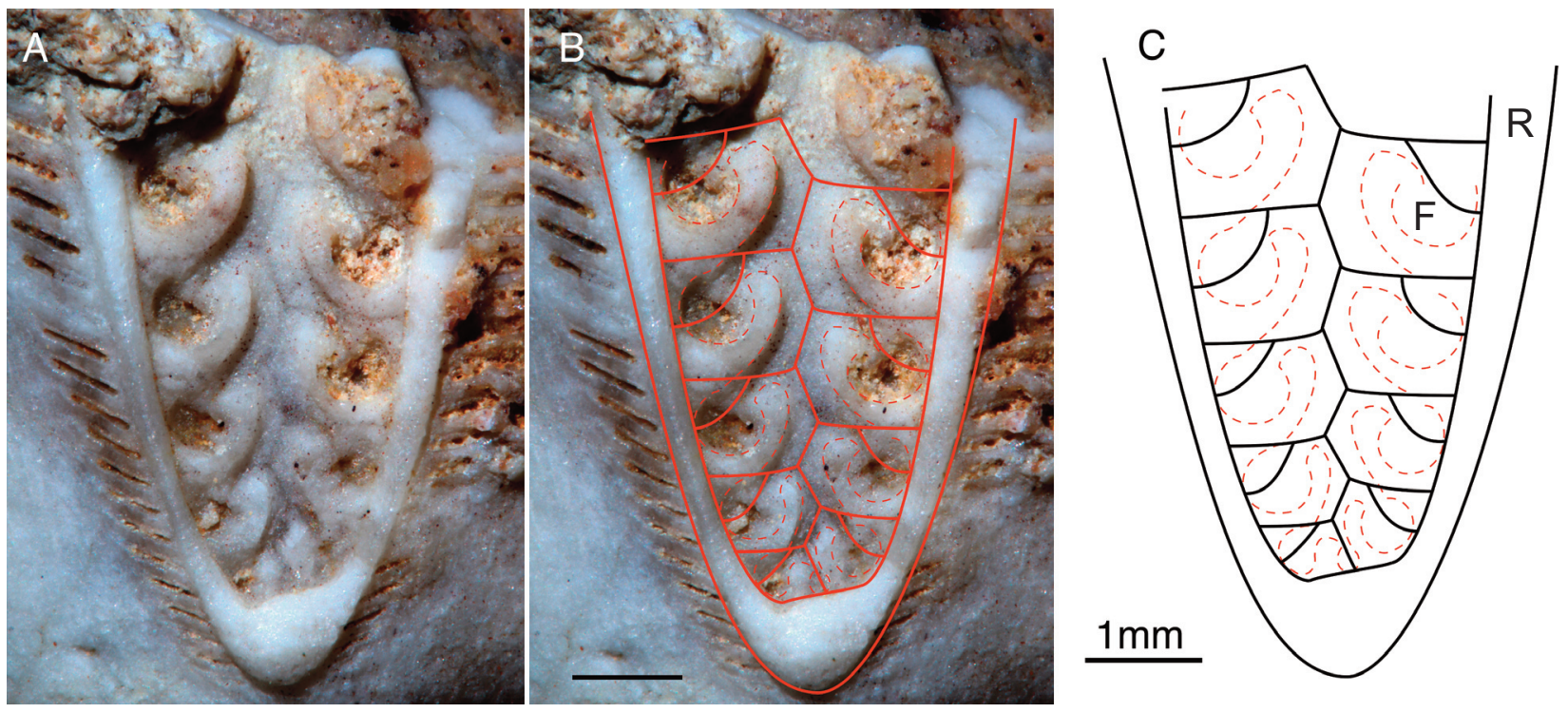

Fig. 4. Arrangement of floor plates in the ambulacra of Cystoblastus kokeni Jaekel, TUG 1727-548, Kukruse Regional Stage (Viivikonna Formation), Kohtla, Estonia. A, photograph of ambulacrum D to show plate sutures, main food groove, facets and slits for pectinirhombs. B, the same with outlines of plate sutures (solid) and ambulacral structures (dashed) superimposed. C, line drawing of plate sutures and ambulacral structures. F, ambulacral facet; R, rim of ambulacrum. Note that the radial plate, which surrounds the ambulacrum, does not continue beneath the ambulacral plates (top). 

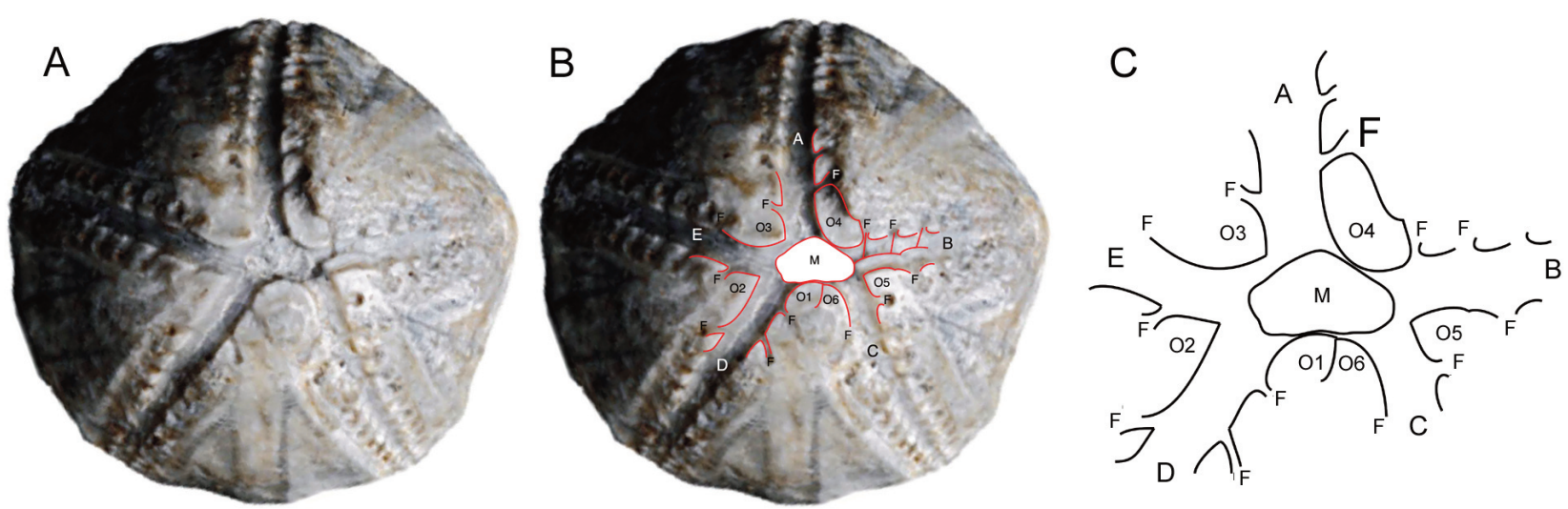

Fig. 5. Oral area of Cystoblastus kokeni Jaekel, PIN3032/1. A, oral view in standard orientation. B, the same with interpretation of oral plates and primary brachiole facets. C, the interpretation, which shows that Cystoblastus primary brachioles displayed the 'B D different' pattern in which the first two facets (F) are to the left as viewed in the growth direction (aborally) in ambulacra B and D, whereas only the first facet is to the left in ambulacra A, C and E. A-E, ambulacra according to Carpenter (1884, 1891); M, mouth; O1-O6 perioral plates. Original photograph from Rozhnov (2014, fig. 1b).

four basals, B4 always has an infralateral (IL4) directly above it, as well as plates above and on either side (IL3 and IL5). L1 lies directly above B1 in Macrocystella (Fig. 7), so it is easy to identify plates L1-L3. Plate L4 is above and to the right of IL4 and often contributes to the right margin of the periproct. So, from this it is easy to deduce that plate L5 is the missing lateral in Cystoblastus. Similarly, R1 is directly above IL1, so again R1-R3 can be recognized. The final two radials allow for alternative interpretations. The radial to the left of L4 might be expected to be R4 and the one to the right of L1, R6. That would be consistent with the situation in the Callocystitidae and Echinoencrinitidae, where R5 is the missing radial and it was our first interpretation. However, when R4 contributes to the periproct border, it is usually on the upper right sector. One

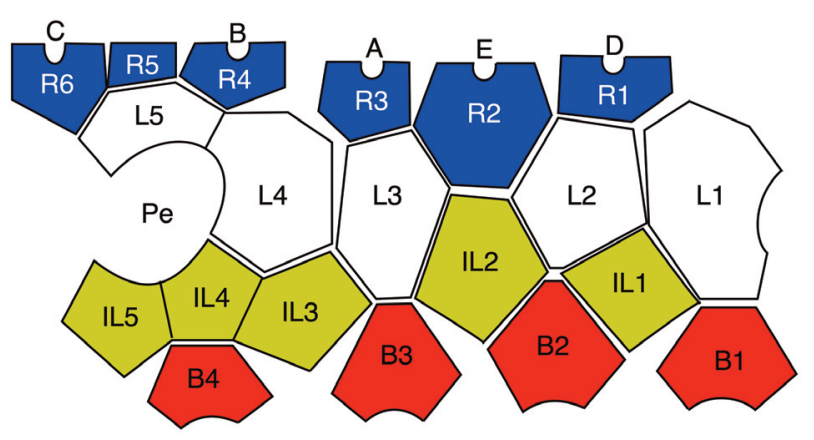

Fig. 6. Diagram to show the arrangement of thecal plates in Cheirocrinus Eichwald, 1856, Ordovician, Russia. A-E, Carpenter's $(1884,1891)$ ambulacra; B1-B4, basal plates; IL1IL5, infralaterals; L1-L5, laterals; Pe, periproct surrounding the anus; R1-R6 radials. Redrawn and relabelled from Paul (1972, fig. 3C, p. 21). example of the cheirocrinid Coronocystis Paul, 1972 also lacks plate L5 and has R5 forming the upper left part of the periproct border. If we can thus identify plates R1-R3 and $\mathrm{R} 5$, the final plate must be R6. At present we accept this interpretation of the plating in Cystoblastus because similar positional constraints show that this is the only acceptable interpretation of the lowest three circlets of plates in all hemicosmitoids if they do indeed possess homologous plates to glyptocystitoids (see below).

Jaekel (1899) thought Cystoblastus was ancestral to the blastoids, largely because of the symmetry of the vault and the ambulacra within deep radial sinuses. However, all blastoids have five 'radials' and five deltoids that form

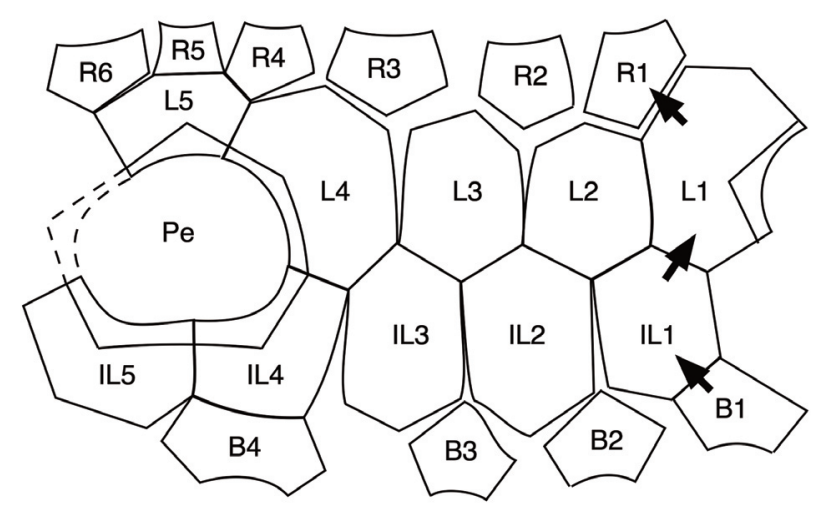

Fig. 7. Plate diagram for Macrocystella Callaway, 1877 to show four closed plate circlets, large periproct $(\mathrm{Pe})$ surrounded by five thecal plates (IL4, IL5, L1, L4 and L5). Arrows indicate the conventional positions of the first plates in each circlet. B1-B4, basals; IL1-IL5, infralaterals; L1-L5, laterals; R1-R6, radials. Redrawn from Paul (1968a, fig. 3, p. 586). 
closed circlets. Furthermore, blastoid ambulacra are always developed on the lancet plates, whereas the ambulacra of Cystoblastus form part of the thecal wall. Paul (2021) has shown that the genus Rhombifera Barrande, 1867 is the glyptocystitoid most closely related to blastoids. It has a small oral area in which five radial plates alternate with five orals and bear an ambulacral facet. Such an arrangement is very closely similar to that found in Lysocystites Miller, 1889, where five facetbearing 'ambulacral' plates alternate with the deltoids. This finally led to the interpretation that all plate circlets of glyptocystitoids and blastoids can be homologized (Paul 2021), and that all pore structures of Rhombifera, Lysocystites, coronates and blastoids are confined to the homologues of glyptocystitoid infralateral and lateral plate circlets.

\section{ORIGIN OF CYSTOBLASTUS}

Cystoblastus possesses pectinirhombs and at least a proximal stem typical of glyptocystitoid rhombiferans. Macrocystella (Fig. 7) has typical glyptocystitoid thecal plating. It lacks the characteristic pore structures of glyptocystitoids, called pectinirhombs. All other families, except the monotypic Cuniculocystidae Sprinkle \& Wahlman (1994), possess pectinirhombs, although one or two genera secondarily lost them. The families Cheirocrinidae Jaekel, 1899, Pleurocystitidae Neumayr, 1889 and Glyptocystitidae retain the six radials, but Cystoblastus lacks plate R4 as discussed above. The families Callocystitidae and Echinoencrinitidae lost plate R5, not R4, so those two families apparently evolved independently from Cystoblastus. Equally, pleurocystitids have a flattened theca one side of which was almost entirely occupied by the periproct and were highly specialized. Thus, it seems most likely that the ancestor of Cystoblastus lay in either the Cheirocrinidae or Glyptocystitidae. Cheirocrinus itself has the infralateral circlet interrupted in the same three places as Cystoblastus but retains six radials and a large periproct surrounded by five plates. Two glyptocystitid genera, Glyptocystella Paul, 1972 and Pirocystella Sprinkle, 1982 (Fig. 8), have a small periproct surrounded by three plates, IL4, L4 and L5, and an infralateral circlet interrupted in two places, but also retain six radials. Both genera have a triangular ridge surrounding the periproct as does $C$. leuchtenbergi according to Volborth's original illustrations (Volborth 1867, pl. 1, figs 3, 5). Thus, it seems wise to include the two glyptocystitid genera in any analysis of Cystoblastus origins. First, it is necessary to consider plate homologies of hemicosmitoid rhombiferans as any new interpretation of plate homologies will affect subsequent character analysis.

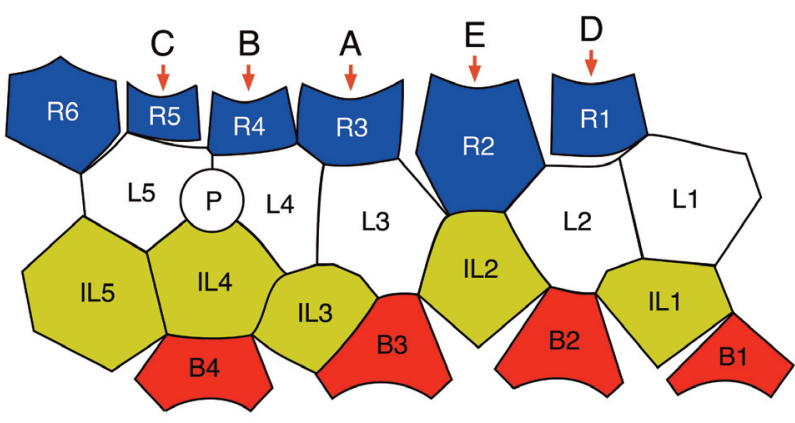

Fig. 8. Plate diagram for the glyptocystitid genus Pirocystella Sprinkle, 1982. Note that the infralateral circlet is interrupted in two places with B2:L2 and B3:L3 sutures, and the lateral circlet once, with the IL2:R2 suture. A-E, ambulacra, which align with the radial plates R1 to R5 (arrows); B1-B4 basal plates; IL1IL5, infralaterals; L1-L5; laterals; P, periproct; R1-R6, radial plates. Redrawn from Sprinkle (1982, fig. 62B, p. 244).

\section{RELATIONSHIP TO HEMICOSMITOIDS}

If one ignores previous interpretations of the plates in Cystoblastus, it has a theca composed of three circlets with, from the stem upwards, four, five and nine plates. Hemicosmitid rhombiferans have the lowest three circlets with four, six and nine plates (Fig. 9A), whereas caryocrinitids are characterized by a theca with just three plate circlets containing four, six and eight plates (Fig. 9B). This seems more than coincidence, so we have attempted to interpret hemicosmitoid plates as homologues of those of glyptocystitoids such as Cystoblastus (Fig. 3).

The Hemicosmitoida consist of three families; the Hemicosmitidae Jaekel, 1918, Caryocrinitidae Bernard, 1895 and Thomacystidae Paul, 1969. They have thecae characterized by definite circlets of plates, referred to by the same names as those in the Glyptocystitoida, but always closed and with different numbers of plates per circlet. So, hemicosmitids have a thecal formula of 4BB, 6ILL, 9LL and 9RR and a lateral periproct (P, Fig. 9A). Caryocrinitids (Fig. 9B) have a formula of 4BB, 6ILL and $8 \mathrm{LL}$ and a periproct on the oral surface (P, Fig. 9C). There are no radials but a heavily plated tegmen orally similar to that seen in camerate crinoids. The unique genus Thomacystis has a plate formula of 3BB, 6ILL and 8LL (Fig. 9D) and a periproct on the margins of the oral surface (P, Fig. 9E). Thomacystis also has a definite oral surface with four ambulacra, five 'oral' plates $(\mathrm{O} 1, \mathrm{O} 2$ and O4-O6, Fig. 9E). By analogy with glyptocystitoid oral surfaces, which have six orals, both ambulacrum A and $\mathrm{O} 3$ are missing in Thomacystis. Hemicosmitids and caryocrinitids are clearly triradiate, with only three ambulacra, which Sumrall (2008) and Sumrall \& Waters (2012) interpreted as paedomorphic. The three ambulacra 


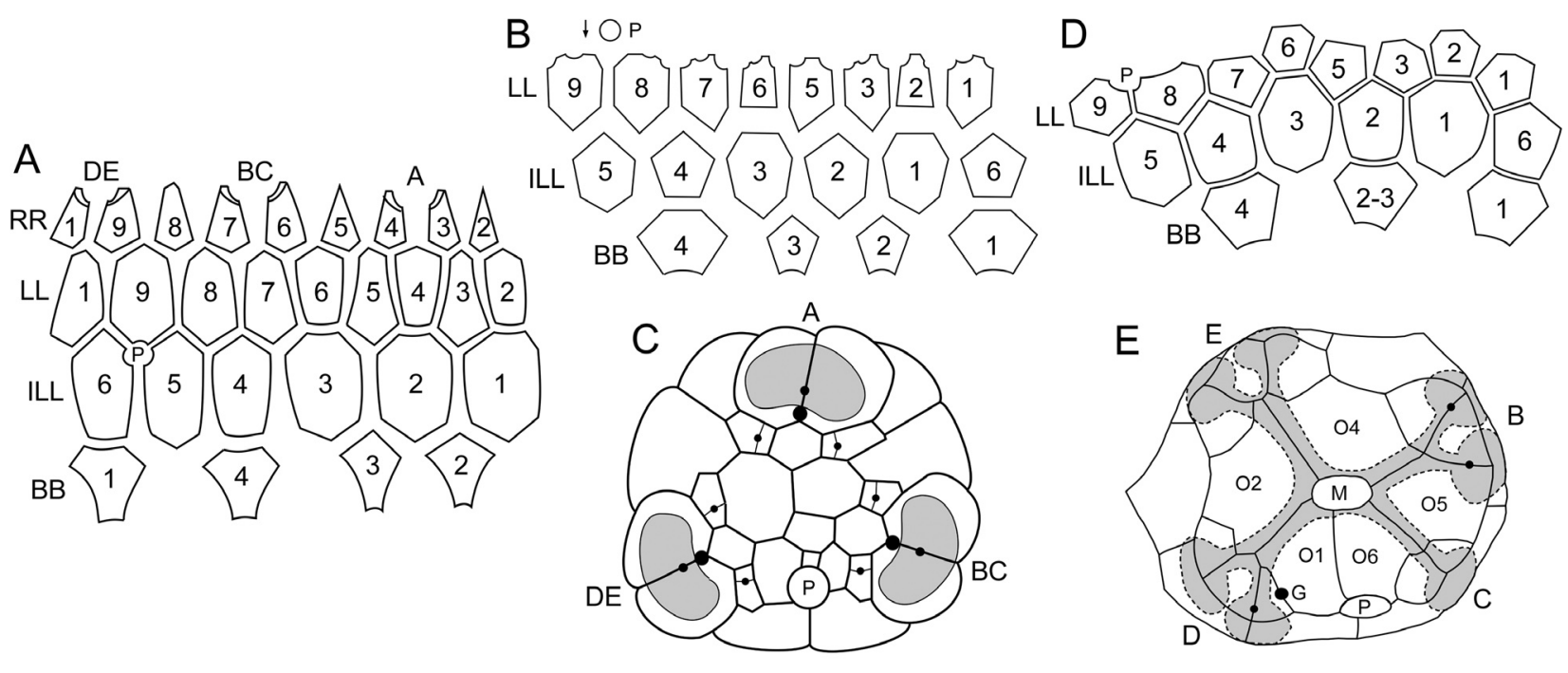

Fig. 9. Standard thecal plate diagrams and oral surfaces to illustrate the main features of the three families of hemicosmitoid rhombiferans. A, Hemicosmites von Buch, 1840. B, Caryocrinites Say, 1825. C, Stribalocystites Miller, 1892. D-E, Thomacystis Paul, 1969. In the Hemicosmitidae (A) there are four plate circlets, basals (BB), infralaterals (ILL), laterals (LL) and radials (RR), with 4, 6, 9 and 9 plates each. Conventional notation numbers plates in each circlet from 1, starting with the basal to the left of the periproct (P) and alternating in successive circlets as in glyptocystitoid rhombiferans (Fig. 6). Caryocrinitids (B, C) and thomacystids $(\mathbf{D}, \mathbf{E})$ have only the lower three plate circlets, both lack plate L4 in the lateral circlet and the periproct is on the oral surface (C, E). In addition, Thomacystis has only three basals (D). Hemicosmitids have three ambulacra always with a single arm facet (A, BC, DE in A), whereas caryocrinitids may have a single facet per ambulacrum (C) or multiple facets in Caryocrinites. Thomacystis has an exposed oral surface with four ambulacra (B-D in $\mathbf{E})$ and five oral plates $(\mathrm{O} 1, \mathrm{O} 2, \mathrm{O} 4-\mathrm{O} 6)$. Glyptocystitoids always have six orals and so it is assumed Thomacystis not only lacks ambulacrum A, but the associated plate $\mathrm{O} 3$ as well. G, gonopore; M, mouth. Arrow and circle labelled $\mathrm{P}$ in $\mathbf{B}$ indicate relative positions of the gonopore and periproct in Caryocrinites. Ambulacra and facets shaded in C and E. Redrawn and relabelled from: A, Bockelie (1979, fig. 4A, p. 371); B, Frest (1975, fig. 2, p. 86); C, Frest (1975, fig. 15, p. 103); D, E, Paul (1984, fig. 87, p. 144).

represent Carpenter's $(1884,1891)$ ambulacrum A, shared BC and shared DE (Fig. 9A, C). Thomacystis has four ambulacra, Carpenter's B-E (Fig. 9E).

Jaekel (1899, fig. 65, p. 254) interpreted the plate circlets of Hemicosmites, Corylocrinus von Koenen, 1886 and Caryocrinites. He showed that the extra infralateral plate of hemicosmitoids was inserted between plates IL1 and IL5 of glyptocystitids (Fig. 8) and identified it by the letter a, rather than a number. In hemicosmitoids all sutures between plate circlets bear cryptorhombs. Thus, it is not possible to identify a basal that is exclusively associated with rhombs, such as occurs in glyptocystitoids. Equally, with six plates in the second circlet there are now two large basals with an extra side, so B4 cannot be recognized on size and shape. Nevertheless, plate B1 is to the left of the periproct in glyptocystitoids, so the left of the pair of large basals is identified as B1 in Hemicosmites (Fig. 10A). Further, traditional positional relationships argue that the plate lying directly above B1 is L1 (Fig. 10). So, the first suggestion is that in hemicosmitoids plate L1 has migrated down to interrupt the normal infralateral circlet between
IL5 and IL1. This leaves nine plates in the combined lateral and radial circlet, a plate arrangement similar to that in Cystoblastus (Fig. 3).

It follows that the nine plates in the third circlet up from the stem in Hemicosmites (Fig. 10A) must include only four laterals (L2-L5) and the remaining five plates are radials. The laterals can be identified because in glyptocystitoid conventional numbering laterals lie above and to the right of infralaterals with the same number. So, in Hemicosmites (Fig. 10A) the plate above and to the right of IL2 is L2. The same relationship occurs for plates IL3 and L3, and for IL4 and L4. In Macrocystella (Fig. 7) a large periproct ensures that IL5 and L5 do not have a common suture, but in genera such as Pirocystella (Fig. 8) L5 lies above and to the right of IL5. So, it becomes possible to suggest where plates L2 to L5 lie in Hemicosmites (Fig. 10A). This leaves five radial plates in the third circlet unaccounted for, up to six of which occur in some glyptocystitoid families.

Nevertheless, in glyptocystitoids radial plates usually lie directly above the infralateral plate of the same number. Thus, the plate directly above IL1 in Fig. 10A 


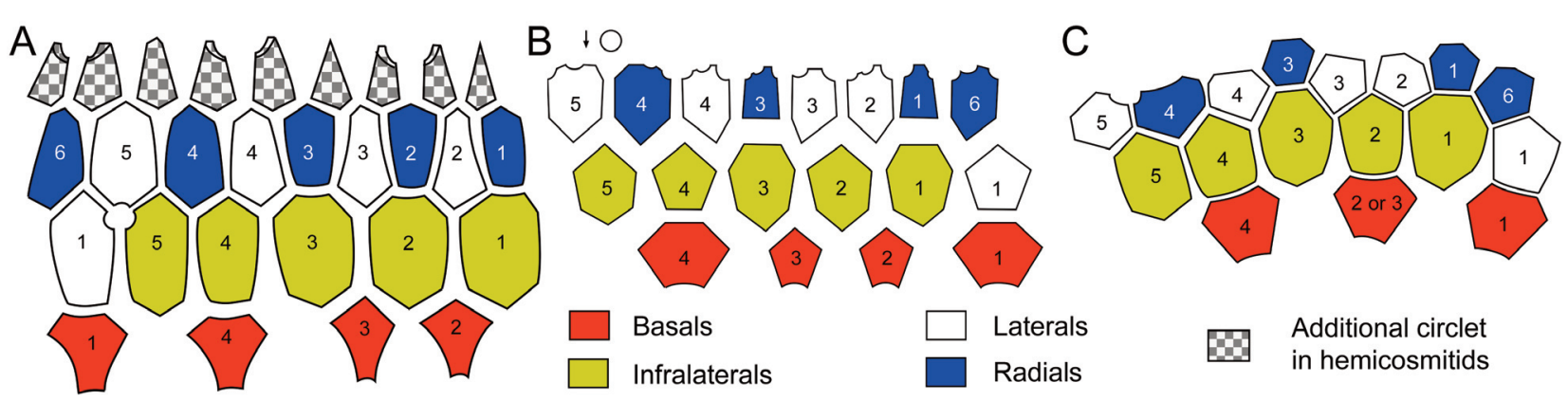

Fig. 10. Reinterpretation of the plate homologies in the lower three circlets of (A) Hemicosmites, (B) Caryocrinites and (C) Thomacystis. The basal circlet is unchanged. The plates in the second circlet are interpreted as plates IL1-IL5 and L1. The nine plates in the third circlet are interpreted as the remaining four laterals L2-L5 and five radials R1-R3 and R5, R6 in Hemicosmites (A). Caryocrinitids (B) and Thomacystis (C) lack R2, the radial plate directly above IL2 in Hemicosmites. Redrawn and relabelled from: A, Bockelie (1979, fig. 4A, p. 371); B, Frest (1975, fig. 2, p. 86); C, Paul (1984, fig. 87A, p. 144). Arrow and circle in B denote positions of gonopore and periproct, respectively.

must be R1. Plates R2 and R3 can be identified in the same way. There is no plate directly above IL4, so no R4 can be identified. Plates L4 and L5 are interpreted to be in their traditional positions with respect to IL4 and IL5, so the remaining two plates in the third circlet could be R5 and R6. One radial contributes to the periproct border and is to the left of L5. Both facts confirm it is R5, and R6 must be the final plate in the third circlet up from the stem. Thus, all the plates of the standard four circlets in glyptocystitoids can be accounted for. Furthermore, the standard positional constraints of glyptocystitoid plate arrangements have not been violated. The five ILL plates lie in exactly the same relationship to the BB in both Hemicosmites (Fig. 10A) and Macrocystella (Fig. 7) or Pirocystella (Fig. 8). Plate L1 has descended into the infralateral circlet in Hemicosmites, compared to Macrocystella, but it is still to the left of IL1. Then the remaining lateral plates have the standard relationship to the infralaterals. Radials have descended into the conventional lateral circlet in Hemicosmites, but retained their conventional position to the left of laterals with the same number.

Comparison of the plate arrangements in both Caryocrinites (Fig. 10B) and Thomacystis (Fig. 10C) shows that the radial plate above IL2, i.e. R2, is missing. They imply that plate R4 is lost in hemicosmitoids and probably in Cystoblastus too (see above). The glyptocystitoid families Callocystitidae and Echinoencrinitidae lost plate R5, whereas the genus Rhombifera Barrande, 1867 which gave rise to the lineage leading to blastoids (Paul 2021) apparently lost plate R6. Thus, it would seem plate reduction in the radial circlet of glyptocystitoids happened at least three times in three separate lineages. The interpretations shown in Fig. 10 are the only possible plate homologies that both identify all plates in the lowest three circlets of hemicosmitoids and satisfy all the positional constraints imposed by the plate arrangement in glyptocystitoid rhombiferans. We feel that this is a strong argument in favour of the new interpretation and that it is worthwhile attempting a phylogenetic analysis using the suggested new plate homologies.

One unsatisfactory aspect of the new interpretation is that Hemicosmites has a fourth circlet of nine plates traditionally regarded as the radial circlet, yet the new interpretation already accounts for five of the radials in the first three circlets. In the type species, H. pyriformis von Buch, 1840 , the nine plates in the fourth circlet are three pairs of adradial plates that share the arm facets and three single inter-radial plates between the pairs of facet-bearing plates. None of these plates bears cryptorhombs. Most other species of Hemicosmites have cryptorhombs developed across all the traditional R:L sutures. They constitute Bockelie's 'system 3' rhombs (Bockelie 1979, fig. 7A, p. 373), the incurrent halves of which lie in the traditional radial plates (Bockelie 1979, fig. 7b). The presence of rhombs suggests these are not axial plates (Paul 2021), so they need accounting for, which is beyond the scope of this paper.

\section{PHYLOGENY}

The genera listed in Table 1 were coded for 27 characters (Table 2) based largely on the new interpretation of the thecal plates in hemicosmitoids. The coding is shown in Table 3 . The phylogenetic analysis produced eight equally parsimonious cladograms of 50 steps, with a consistency index of 0.720 , a retention index of 0.839 and a rescaled consistency index of 0.604 .

The strict consensus tree derived from the eight most parsimonious trees resulting from a branch and bound 
Table 1. Key genera discussed in the text

\begin{tabular}{|c|c|c|c|c|}
\hline Higher taxon & Family & Genus & Age & Key reference \\
\hline 'Out group' & Macrocystellidae & Macrocystella & Tremadoc & Paul 1984; Nardin et al. 2009 \\
\hline \multirow[t]{7}{*}{ Glyptocystitoida } & Cheirocrinidae & Cheirocrinus & M-U Ordovician & Paul 1972 \\
\hline & & Sprinkleocystis & Upper Sandbian & Broadhead \& Sumrall 2003 \\
\hline & Glyptocystitidae & Glyptocystella & Sandbian & Paul 1972; Sprinkle 1982 \\
\hline & & Pirocystella & Sandbian & Sprinkle 1982 \\
\hline & Cystoblastidae & Cystoblastus & Sandbian & Herein \\
\hline & Callocystitidae & Lepadocystis & Katian & Sumrall \& Carlson 2000; Sumrall \& Waters 2012 \\
\hline & & Maennilocystis & Katian & Paul \& Rozhnov 2016 \\
\hline \multirow[t]{4}{*}{ Hemicosmitoida } & Caryocrinitidae & Caryocrinites & Katian-Silurian & Frest 1975; Sprinkle 1975; Lanc et al. 2015 \\
\hline & & 'Paracaryocrinites' & Darriwilian & $\begin{array}{l}\text { Nikolai Semenov (personal communication } \\
\text { 9-2019) }\end{array}$ \\
\hline & Hemicosmitidae & Hemicosmites & $\mathrm{M}-\mathrm{U}$ Ordovician & $\begin{array}{l}\text { Bockelie 1979; Sumrall \& Waters 2012; } \\
\text { N. Semenov }\end{array}$ \\
\hline & Thomacystidae & Thomacystis & Katian & Paul 1984 \\
\hline
\end{tabular}

Table 2. Character states in Cystoblastus cladograms

\begin{tabular}{|c|c|c|c|c|c|}
\hline No. & Character & & Plesiomorphic & Apomorphic & \\
\hline 1 & Proximal stem & Present & Absent & - & - \\
\hline 2 & B1:L1 suture & Absent & Present & - & - \\
\hline 3 & B2:L2 suture & Absent & Present & - & - \\
\hline 4 & B3:L3 suture & Absent & Present & - & - \\
\hline 5 & Basal rhombs & None & Two & One & Ten \\
\hline 6 & IL1:R1 suture & Absent & Present & - & - \\
\hline 7 & IL2:R2 suture & Absent & Present & - & - \\
\hline 8 & IL3:R3 suture & Absent & Present & - & - \\
\hline 9 & Number of laterals & Five & Four & - & - \\
\hline 10 & $\mathrm{~L} 1$ & In $L$ circlet & In IL circlet & - & - \\
\hline 11 & L5 & Present & Absent & - & - \\
\hline 12 & Number of radials & Six & Five & Four & - \\
\hline 13 & $\mathrm{R}$ circlet & Closed & Open & Alternate & - \\
\hline 14 & $\mathrm{R} 4$ & Present & Absent & - & - \\
\hline 15 & R5 & Present & Absent & - & - \\
\hline 16 & R2 & Present & Absent & - & - \\
\hline 17 & Type of rhomb & None & Pectinirhombs & Cryptorhombs & - \\
\hline 18 & Dichopore type & Absent & Discrete & Confluent & Covered \\
\hline 19 & Periproct $(\mathrm{Pe})$ & Large lateral & Small lateral & Small oral & - \\
\hline 20 & Periproct with triangular rim & No & Yes & - & - \\
\hline 21 & IL5 in periproct border & Yes & No & - & - \\
\hline 22 & $\mathrm{~L} 1$ in periproct border & Yes & No & - & - \\
\hline 23 & L4 in periproct border & Yes & No & - & - \\
\hline 24 & L5 in periproct border & Yes & No & - & - \\
\hline 25 & $\mathrm{R} 5$ in periproct border & No & Yes & - & - \\
\hline 26 & Number of ambulacra & Five & Four & Three & - \\
\hline \multirow[t]{2}{*}{27} & Ambulacra & Mural & Epithecal & Erect & - \\
\hline & Code & 0 & 1 & 2 & 3 \\
\hline
\end{tabular}

search rooted on Macrocystella is shown in Fig. 11. This shows the hemicosmitoids as the most derived taxon, with Hemicosmites as the primitive sister group within a trichotomy involving the caryocrinitids and Thomacystis. It also shows Cystoblastus as the primitive sister group of the hemicosmitoids. Cystoblastus is part of a trichotomy involving the glyptocystitid genera, Glyptocystella and Pirocystella. This whole lineage has Cheirocrinus as its primitive sister group. The other cheirocrinid, Sprinkleocystis and the two callocystitid genera are involved in another trichotomy separate from the lineage to the hemicosmitoids, which is not at all unexpected. Altogether, this interpretation is an improvement on the previous state of knowledge concerning the origin of the 


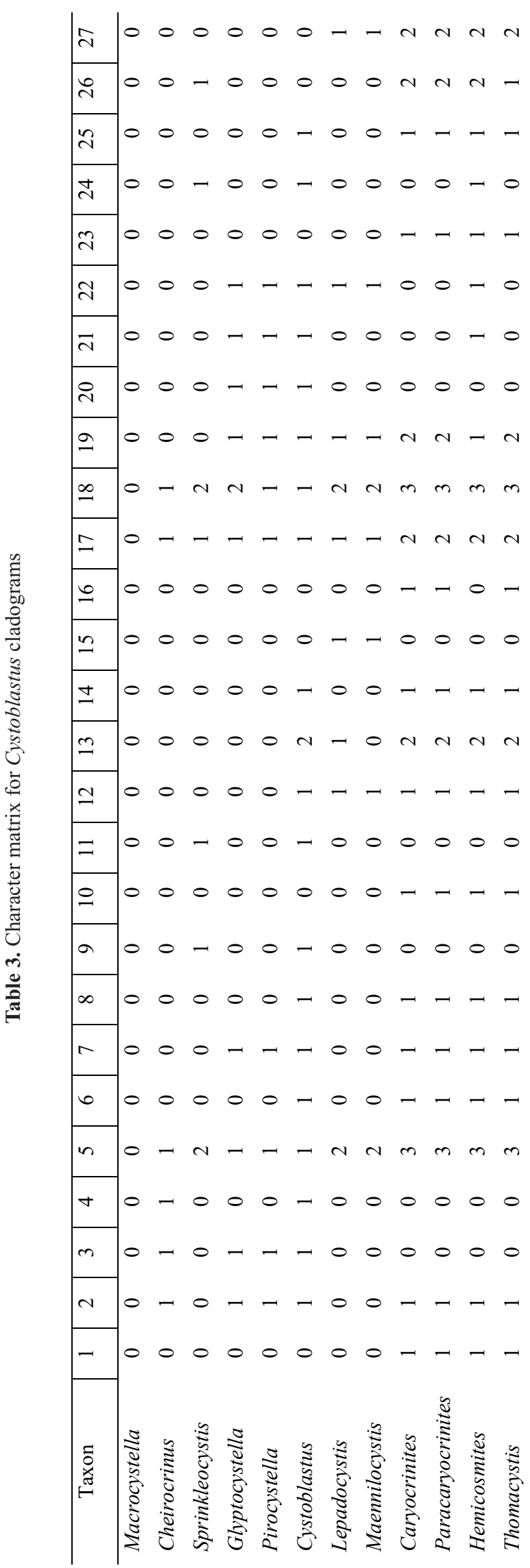

hemicosmitoids (Paul 2021, fig. 25), which merely showed them as a separate lineage sister to the blastoid lineage. The new interpretation of hemicosmitoid thecal plating seems justified.

\section{MODE OF LIFE}

The B2:L2 suture of Cystoblastus is sinuous and remarkably symmetrical (Fig. 2D). On either side the B1:L1 suture slopes one way and the B3:L3 suture slopes the other way (Fig. 2A), thus maintaining the symmetrical effect and, of course, B2 is exactly anterior. Thus, in the vault $\mathrm{L} 2$ is anterior and the eight other plates are disposed four on each side with the L4:R5 suture exactly posterior and terminating below in the periproct (Fig. 12). So, it seems the nine plates of the vault maintain a symmetrical disposition about the anterior-posterior axis (as defined by $\mathrm{B} 2$ and the periproct). Furthermore, the three orals that are large and fairly obvious on TUG 1086-3 are also disposed symmetrically. Plate L4 is the lateral that tapers to a point and the three large orals sit on top of L1, L2 and L3. Within the limitations of the vault being composed of four laterals and five radials, it is about as symmetrical as possible. Furthermore, the R3:L4 and R5:L4 rhombs are the ones with the longest slits and the narrowest interval separating the two half rhombs within L4.

Similarly, the plate arrangement in hemicosmitoids involves a sixth 'infralateral' (Jaekel's 1899, 'ILa', which corresponds to glyptocystitoid L1), which migrated down into the infralateral circlet as the periproct shrank and became centred in the $\mathrm{BC}$ interray, rather than the $\mathrm{CD}$ interray. Plate R2 in Hemicosmites is anterior with respect to the periproct (Fig. 10A) and has four plates on either side of it. The periproct is slightly off the exact opposite of R2, but in hemicosmitoid genera with only eight 'lateral' plates the symmetry is restored as R2 is lost (Fig. 10B, C). Thus, they have an anterior suture (between L2 and L3) and an exactly posterior periproct and again four plates on either side between the anterior suture and the posterior periproct. We do not understand the reasons for the symmetry, but it does suggest that both Cystoblastus and all hemicosmitoids rearranged their plates for similar reasons.

The plane of symmetry has potential consequences for both taxa. If attached, as we know Caryocrinites was (Brett 1978), currents might bend the theca over until the oral-aboral axis was horizontal. In fossils that means the external currents flowed up the theca from the stem attachment towards the mouth. It seems unlikely that the living animals would have preferentially adopted an orientation with the plane of symmetry horizontal or oblique, although in theory the animals would have no control over the external current direction. Nevertheless, 


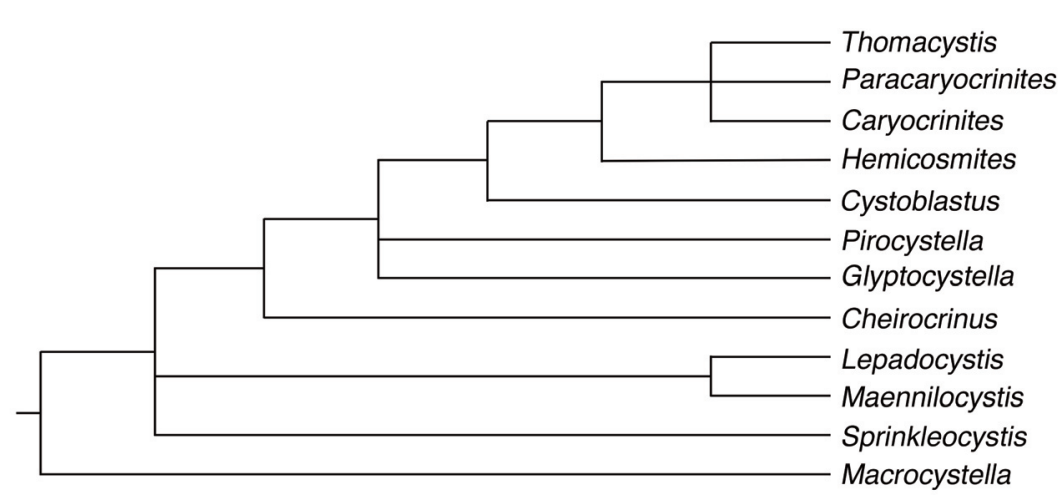

Fig. 11. Strict consensus tree derived from the eight most parsimonious trees for the genera in Table 1. The tree was rooted on Macrocystella and identifies the hemicosmitoids as the most derived group, with Cystoblastus as their immediate sister group. The glyptocystitids Glyptocystella and Pirocystella are part of a trichotomy, but both more closely related to Cystoblastus and the hemicosmitoids than Cheirocrinus. Among the hemicosmitoids, Hemicosmites is plesiomorphic and a sister group to the caryocrinitids, Caryocrinites and Paracaryocrinites, plus Thomacystis, which form a second trichotomy. Sprinkleocystis and the callocystitids, Lepadocystis and Maennilocystis form a separate lineage.

if the plane of symmetry were vertical, the anus could either be at the top or the bottom. It seems unlikely that it would be at the top. Voiding faecal pellets would miss the two lateral ambulacra in triradiate hemicosmitoids, tetraradiate Thomacystis and pentaradiate Cystoblastus if the anus were below. Developing a more adoral periproct, as in Caryocrinites and Thomacystis, moved it downstream with respect to external currents and would assist in faecal pellets avoiding ambulacra. With four ambulacra, Thomacystis may have evolved as an adaptation to tidal currents or even waves, and therefore may have lived in shallower water than other hemicosmitoids.

The proximal stem was very flexible in Cystoblastus. Thus, in theory the theca could be orientated, so the periproct was down (towards the substrate) no matter what the prevailing current direction. However, it seems unnecessary to improve the symmetry of the theca unless this was in response to interactions with currents. In

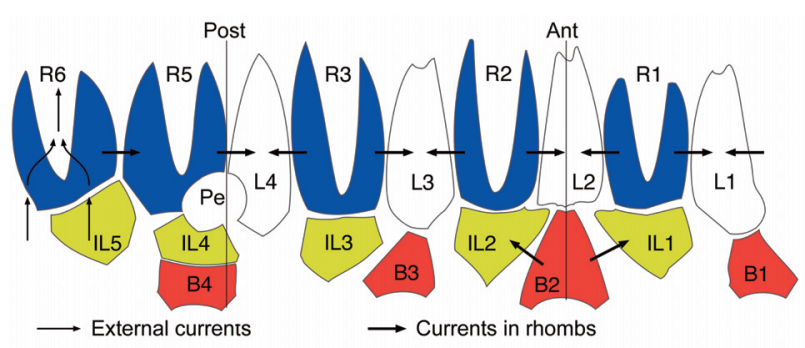

Fig. 12. Plate arrangement of Cystoblastus with external currents, currents within pectinirhombs and plane of anterior-posterior symmetry indicated. Ant, anterior; B1-B4, basals; IL1-IL5; infralaterals; L1-L4, laterals; Pe, periproct; Post, posterior; R1R3, R5, R6, radial plates. External currents only shown in R6. One arrow for each pectinirhomb. hemicosmitoids the glyptocystitoid proximal stem is not developed and so the symmetry alone would affect the orientation of the theca in currents. This leads to the conclusion that thecal symmetry in both Cystoblastus and the hemicosmitoids enabled them to develop a fixed orientation with respect to prevailing currents. This idea suggests that both taxa lived below storm wave base, but it needs experimental investigation.

In Cystoblastus currents flowed through the basal rhombs from the basal plates to the infralaterals. In the vault rhombs currents entered the radials and exited the laterals, with the exception of the R6:R5 rhomb, where they flowed from R6 to R5 (Fig. 12). In glyptocystitoids with R:L rhombs the currents flowed from the radials to the laterals (Paul 1968b, figs 31, 33, 34, 36), so this flow direction in Cystoblastus was likely inherited. The slits in the R3:L4 and R5:L4 rhombs are significantly longer than in any other rhomb (Fig. 1G), suggesting they had a greater capacity. The reasons for this are obscure, but plate L4 very frequently bears one or more pectinirhombs in other glyptocystitoids. Theoretically, in a horizontal Cystoblastus theca bent over by currents, the external current would flow sub-parallel to the ciliary currents within the basal pair of rhombs, irrespective of the direction in which the theca was bent over. Similarly, the currents in the vault rhombs would flow around the theca, perpendicular to the external current. This has consequences for all glyptocystitoids with intra-circlet sutures, such as the R:R rhombs of cheirocrinids and glyptocystitids, and the IL:IL and L:L rhombs of Rhombifera Barrande, 1867. In Cystoblastus, if the anus were below in a horizontal theca, the two basal rhombs would have been above, a position in which external currents would have reinforced the currents within the rhombs. 
In all hemicosmitoids currents within the B:IL rhombs would also flow sub-parallel to the external current, but currents within all L:IL and R:L rhombs would flow counter to any external current that bent the theca to a horizontal orientation. Presumably, cilia within the dichopores would still have been able to induce adequate currents for respiratory exchange.

Feeding currents would encounter a bent over theca at the basals and flow 'up' the theca towards the mouth. They would encounter a palisade of closely spaced brachioles disposed along the ambulacra and would pass between the brachioles from the aboral (outer) side towards the adoral side, thus converging on the central food groove in all ambulacra and flowing away from the theca. The resistance of the palisade of brachioles to the current would assist in part of the current entering the slits in the radial plates, which line the edges of the ambulacra. The sole exception to this was the exit of the R6:R5 rhomb. The prominent rims around the ambulacra appear to have been barriers to prevent water flowing either from within the ambulacra out towards the rhombs or the other way.

Acknowledgements. Financial support to Ursula Toom was provided by Estonian Research Council grant PRG836. We are grateful to Gennadi Baranov, Department of Geology, Tallinn University of Technology, for patient digital photographing of the specimens without which the paper would have been impossible, and to Mare Isakar for access to the geological collections of the University of Tartu. We thank Georgi Iskyl from VSEGEI in St Petersburg for his help in acquiring research papers and John Marriage of Uplyme, UK, for technical assistance. Christopher Paul is grateful to originators of the 'Geocollections of Estonia' website, without which the discrepancy between published plate diagrams and the actual specimens would have continued unnoticed. Thoughtful reviews by J. Sprinkle and S. Rozhnov improved the original manuscript considerably. The publication costs of this article were covered by the Estonian Academy of Sciences.

\section{REFERENCES}

Barrande, J. 1867. Classe des Mollusques, Ordre des Ptéropodes. Systême Silurien du Centre de la Bohême, Premier Partie: Recherches Paléontologiques, 3, W. Waagen, Prague, xv + $179 \mathrm{pp}$.

Bassler, R. S. \& Moodey, M. W. 1943. Bibliographic and faunal index of Paleozoic pelmatozoan echinoderms. Geological Society of America Special Paper, 45, vi +733 pp.

Bather, F. A. 1899. A phylogenetic classification of the Pelmatozoa. Report of the British Association for the Advancement of Science, 68, 916-923.

Bekker, H. 1921. The Kuckers Stage of the Ordovician Rocks of NE Estonia. C. Mattlesen, Tartu, 92 pp.
Bernard, F. 1893-1895. Eléments de Paléontologie. J.-B. Ballière et Fils, Paris, viii +1168 pp.

Bockelie, J. F. 1979. Taxonomy, functional morphology and palaeoecology of the Ordovician cystoid family Hemicosmitidae. Palaeontology, 22, 363-406.

Bockelie, J. F. 1984. The Diploporita of the Oslo region, Norway. Palaeontology, 27, 1-68.

Brett, C. E. 1978. Attachment structures in the rhombiferan cystoid Caryocrinites and their paleobiological significance. Journal of Paleontology, 52, 717-726.

Broadhead, T. E. \& Sumrall, C. D. 2003. Heterochrony and paedomorphic morphology of Sprinkleocystis ektopios, new genus and species, (Rhombifera, Glyptocystida [sic]) from the Middle Ordovician (Caradoc) of Tennessee. Journal of Paleontology, 77, 113-120.

Buch, L. von. 1840. Über Sphaeroniten und einige andere Geschlechter, aus welchen Crinoideen entstehen. Verhandlungen Königlich Preussische Akademie der Wissenschaften zu Berlin, (1840), 56-60.

Callaway, C. 1877. On a new area of Upper Cambrian rocks in south Shropshire, with a description of a new fauna. Quarterly Journal of the Geological Society, London, 33, 652-672.

Carpenter, P. H. 1884. Report upon the Crinoidea collected during the voyage of HMS Challenger during the years 1873-76, part 1. General morphology with descriptions of the stalked crinoids. Reports of the Scientific Results of the Voyage of HMS Challenger, Zoology, 11, 1-442.

Carpenter, P. H. 1891. On certain points of the morphology of the Cystidea. Journal of the Linnean Society (Zoology), 34, $1-52$.

Eichwald, E. von. 1856. Beitrag zur geographischen Verbreitung der fossilien Thiere Russlands. Alte Periode. Bulletin de la Société Impériale des Naturalistes de Moscou, 29, 88127.

Frest, T. J. 1975. Caryocrinitidae (Echinodermata: Rhombifera) of the Laurel Limestone of southeastern Indiana. Fieldiana: Geology, 30, 81-106.

Hecker (Gekker), R. F. 1964. Class Cystoidea. In Osnovy paleontologii. Iglokozhie, gemihordovye, pogonofory $i$ shetinkochelyustnye [Fundamentals of Palaeontology, Echinoderms, Hemichordates, Pogonophores and Chaetognaths] (Hecker, R. F., ed.), pp. 30-45. Nedra, Moscow [in Russian].

Jaekel, O. 1899. Stammesgeschichte der pelmatozoen. 1. Thecoidea und Cystoidea. Julius Springer, Berlin, $442 \mathrm{pp}$.

Jaekel, O. 1918. Phylogenie und System der Pelmatozoen. Paläontologisches Zeitschrift, 3, 1-128.

Jefferies, R. P. S., Joysey, K. A., Paul, C. R. C. \& Ramsbottom, W. H. C. 1967. Echinodermata: Pelmatozoa. In The Fossil Record (Harland, W. B. et al., eds), pp. 565-581. Geological Society, London.

Kesling, R. V. 1961. Notes on Jaekelocystis hartleyi and Pseudocrinites gordoni, two rhombiferan cystoids described by Charles Schuchert in 1903. Contributions from the Museum of Paleontology, University of Michigan, 16, 245-273.

Kesling, R. V. 1962. An interpretation of Rhombifera bohemica Barrande, 1867, an unusual hydrophoridean cystoid. 
Contributions from the Museum of Paleontology, University of Michigan, 17, 277-289.

Kesling, R. V. 1968. Cystoids. In Treatise on Invertebrate Paleontology, Part S, Echinodermata 1 (1) (Moore, R. C., ed.), pp. S85-S267. Geological Society of America \& University of Kansas Press, Boulder \& Lawrence.

Koenen, A. von. 1886. Ueber neue Cystideen aus den Caradocschichten der Gegend von Montpellier. Neues Jahrbuch für Mineralogie, Geologie und Paläontologie, 2, 246-254.

Kröger, B. 2012. The "Vaginaten": the dominant cephalopods of the Baltoscandian Mid Ordovician endocerid limestone. Geologiska Föreningens i Stockholm Förhandlingar, 134, 115-132.

Lanc, F. A., McDermott, P. D. \& Paul, C. R. C. 2015. The identity of the British Ordovician cystoid "Hemicosmites rugatus Forbes”. Geological Journal, 50, 1-16.

Miller, S. A. 1889. North American Geology and Palaeontology. Western Methodist Book Concern, Cincinnati, Ohio, 664 pp.

Miller, S. A. 1892. Palaeontology. Annual Report, Indiana Department of Geology and Natural Resources, 17, 611705.

Nardin, E., Lefebvre, B., David, B. \& Mooi, R. 2009. La Radiation des échinodermes au Paléozoïque inférieur, l'exemple des blastozoaires. Comptes Rendus Paleovol, 8 , $179-188$.

Neumayr, M. 1889. Die Stämme des Thierreiches. 1. Wirbellose Thiere. Tempsky: Vienna and Prague; 603 pp.

Öpik, A. 1925. Beiträge zur Kenntnis der Kukruse- (C2-) Stufe in Eesti 1. Acta et Commentationes Universitas Dorpatensis, 8(5), 1-18.

Paul, C. R. C. 1967. The British Silurian cystoids. Bulletin of the British Museum (Natural History) Geology, 13, 299-355.

Paul, C. R. C. 1968a. Macrocystella Callaway, the earliest glyptocystitid cystoid. Palaeontology, 11, 580-600.

Paul, C. R. C. 1968b. Morphology and function of dichoporite pore structures in cystoids. Palaeontology, 11, 697-730.

Paul, C. R. C. 1969. Thomacystis, a unique new hemicosmitid cystoid from Wales. Geological Magazine, 106, 190-196.

Paul, C. R. C. 1972. Cheirocystella antiqua gen. et sp. nov. from the Lower Ordovician of western Utah, and its bearing on the evolution of the Cheirocrinidae (Rhombifera: Glyptocystitida). Brigham Young University Geology Studies, 19, 15-63.

Paul, C. R. C. 1984. British Ordovician Cystoids, part 2. Monographs of the Palaeontographical Society, 136(563), 65-152.

Paul, C. R. C. 2021. New insights into the origin and relationships of blastoid echinoderms. Acta Palaeontologica Polonica, 66, 41-62.

Paul, C. R. C. \& Bolton, T. E. 1991. A new Middle Silurian callocystitid cystoid from the Lake Timiskaming Region, Northern Ontario. Bulletin of the Geological Survey of Canada, 412, 35-42.

Paul, C. R. C. \& Rozhnov, S. V. 2016. Revision of Scoliocystis (Rhombifera; Echinoencrinitidae) and related cystoid genera. Paleontological Journal, 50, 43-63.

Pearce, J. C. 1843. On an entirely new form of encrinite from the Dudley Limestone. Proceedings of the Geological Society, London, 4, 160.
Piveteau, J. 1952. Traité de Paléontologie, vol. 3, Les formes ultimes d'Invertébrés: morphologie et évolution. Masson et cie, Paris, $1064 \mathrm{pp}$.

Regnéll, G. 1945. Non-crinoid Pelmatozoa from the Paleozoic of Sweden. A taxonomic study. Meddelanden från Lunds Geologisk-Mineralogiska Institution, 108, 1-255.

Rozhnov, S. 2014. Symmetry of echinoderms: from initial bilaterally-asymmetric metamerism to pentaradiality. Natural Science, 6, 171-183.

Say, T. 1825. On two genera and several species of Crinoidea. Journal of the Academy of Natural Sciences, Philadelphia, 4, 289-296.

Schuchert, C. 1904. On Siluric and Devonic Cystidea and Camarocrinus. Smithsonian Miscellaneous Collections, 2 , 201-272.

Sinclair, G. W. 1945. Some Ordovician echinoderms from Oklahoma. American Midland Naturalist, 34, 707-716.

Sprinkle, J. 1973. Morphology and evolution of blastozoan echinoderms. Special Publication, Museum of Comparative Zoology, Harvard, 1-284.

Sprinkle, J. 1975. The "arms" of Caryocrinites, a rhombiferan cystoid convergent on crinoids. Journal of Paleontology, 49, 1062-1073.

Sprinkle, J. 1982. Cylindrical and globular rhombiferans. In Echinoderm Faunas from the Bromide Formation (Middle Ordovician) of Oklahoma (Sprinkle, J., ed.), University of Kansas Paleontological Contributions, Monograph, 1, 231-273.

Sprinkle, J. \& Wahlman, G. P. 1994. New echinoderms from the early Ordovician of West Texas. Journal of Paleontology, 68, 324-338.

Sumrall, C. D. 2008. The origin of Lovén's law in glyptocystitoid rhombiferans and its bearing on the plate homology and heterochronic evolution of the hemicosmitoid peristomial border. In Echinoderm Paleobiology (Ausich, W. I. \& Webster, G. D., eds), pp. 228-241. Indiana University Press, Bloomington.

Sumrall, C. D. \& Brett, C. 2002. A revision of Novacystis hawkesi Paul and Bolton 1991 (Middle Silurian: Glyptocystitida, Echinodermata) and the phylogeny of early callocystitids. Journal of Paleontology, 76, 733740.

Sumrall, C. D. \& Carlson, D. T. 2000. Suture modification by pectinirhomb growth in Lepadocystis decorus, a new species of callocystitid glyptocystitid rhombiferan (Echinodermata) from Illinois. Journal of Paleontology, 74, 487-491.

Sumrall, C. D. \& Waters, J. A. 2012. Universal elemental homology in glyptocystitoids, hemicosmitoids, coronoids and blastoids: steps towards echinoderm phylogenetic reconstruction in derived Blastozoa. Journal of Paleontology, 86, 956-972.

Swofford, D. L. 2003. PAUP* Version 4.0.b10: phylogenetic analysis using parsimony and other methods. Sinauer Associates, Sunderland, MA.

Volborth, A. von. 1867. O tsistoblastakh, novom rode morskikh lilij ili krinoidej [On Cystoblastus, a new genus of sea lilies or crinoids]. Tipografiya Imperatorskoj Akademii Nauk, St Petersburg, 12 pp. [in Russian]. 
Wanner, J. 1933. Handwörterbuch der Naturwissenschaften. Stachelhäuter (Paläontologie), pp. 485-516. Fischer, Jena [not seen].

Yakovlev, N. N. 1926a. Sur le Cystoblastus, Nymphaeoblastus et Acrocrinus. Izvestiya Geologicheskogo Komiteta, Leningrad, 45(2), 43-49 [in Russian].

Yakovlev, N. N. 1926b. Some new data on Cystoblastus. Annuaire de la Société Paléontologique de Russie, 4, 2328 [in Russian, with English summary].
Yakovlev, N. N. 1931. Sur les pores primaires de Cystoblastus. Annuaire de la Société Paléontologique de Russie, 9, 4345 [in Russian, with French summary].

Yanishevskii, M. E. 1932. Geologicheskaya karta okrestnostej g. Leningrada: Opisanie geologicheskogo stroeniya okrestnostej g. Slutska [Geological Map of the Environs of Leningrad: Description of the Geology of the Environs of the Town of Slutsk]. Trudy VGRO, Vypusk 126, 119 pp. [in Russian].

\title{
Cystoblastus'e ja Hemicosmitoida (Echinodermata: Blastozoa) põlvnemine
}

\author{
Christopher R. C. Paul ja Ursula Toom
}

Kõik varasemad Cystoblastus Volborthi skeletiplaatide kirjeldused ja nende tõlgendused kujutavad suletud infralateraalset ringplaadistikku, kuid meie kirjeldatud eksemplaridel on see plaatide ring kolmest kohast avatud. Cystoblastus on ümber kirjeldatud Eestist kogutud materjali põhjal. Sellel on blastoididele omane karikas, mille alus koosneb neljast basaal- ja viiest infralateraalplaadist. Alusele järgneva võlvi plaadistik koosneb üheksast vaheldumisi asetsevast lateraalja radiaalplaadist. Radiaalplaadid on ambulakraalsüsteemide äramahutamiseks sügavalt lõhestatud nagu blastoididel, kuid neil puuduvad blastoididele omased lantsett- ja ka deltoidplaadid. Kuna Cystoblastus'e karika võlvi plaadistik sarnaneb hemikosmitoidi Rhombifera lateraalplaatide ringiga, siis prooviti tuvastada rombiiferate, glüptotsüstitoidi ja hemikosmitoidi (= dihhoporiid) skeletiplaatide homoloogiaid. See ainulaadne tõlgendus hõlmab kõikide hemikosmitoidide skeletiplaate, seejuures minemata vastuollu glüptotsüstitoidi plaadistikuga. Tavapärased homoloogiatestid ei muuda uut tõlgendust kehtetuks. Uute plaadihomoloogiate abil uurisime glüptotsüstitoidide ja hemikosmitoidide fülogeneesi, kasutades selleks 12 erinevat perekonda ning 27 parsimoonia parameetrit. Kladistiline analüüs, kasutades PAUP-i, andis kaheksa võrdselt parsimaalset puud. Rangeimate kokkusobivustega evolutsioonipuu tuvastas, et hemikosmitoidid on oma päritolult dihhoporiidid, kusjuures Hemicosmites on Caryocrinitidae ja Thomacystidae sõsartakson. Cystoblastus on hemikosmitoidide sõsarrühm kolmikjaotuses, mis sisaldab veel perekondi Glyptocystella ja Pirocystella ning põlvneb Cheirocrinidae seast. Seega ei ole Cystoblastus suguluses blastoididega, nagu soovitas Otto Jaekel, vaid moodustab olulise ühenduslüli glüptotsüstitoidide ja hemikosmitoidsete dihhoporiidide vahel ning Dichoporita on kehtiv takson. 